\title{
Teachers' Perceptions about Language Learning Difficulties in English as a Foreign Language EFL Classes
}

\author{
Haggag Mohamed Haggag, PhD \\ Assistant Professor of Curricula \& TEFL Methodology \\ South Valley University, Egypt \\ Eman Mohy-Eldeen Bakr, PhD \\ Doctor of Curricula \& TEFL Methodology \\ Egyptian Ministry of Education, Egypt
}

Doi:10.19044/esj.2020.v16n19p120 URL:http://dx.doi.org/10.19044/esj.2020.v16n19p120

\begin{abstract}
The research aimed at verifying English language teachers' perceptions about English language learning difficulties in their classes. Using a descriptive analytical approach, it utilized a questionnaire which included (60) items which were divided over four parts; the first was about the basic concepts, the second was about the intervention techniques, the third included class barriers while the fourth was about class assessment techniques. The second instrument is an online reflection journal to record participants' views about language learning difficulties. The participants (N. 99) were English language teachers from different stages at The Red Sea Governorate in Egypt. Following a descriptive analytical research design, the research utilized the instruments to record the results and interpret them in the light of its hypotheses. Results showed that there was a strong correlation between participants' concepts over the four parts of the questionnaire (basic concepts, intervention techniques, class barriers and assessment techniques. Results also showed that there were significant mean differences between participant's scores in the four parts of the questionnaire favoring the concepts part. Recommendations of the research included integrating language learning difficulties modules in both pre-service and in-service teachers' education and training programs as well as highlighting intervention techniques in EFL curricula as well as LD assessment procedures and techniques.
\end{abstract}

Keywords: Perception, Learning, Difficulties, EFL 


\section{Introduction}

There is a growing concern for students with Learning Difficulties LD, therefore, teachers should identify and help these students along with the parents. Learning difficulties are caused by a combination of factors such as poor quality training and inadequate school curriculum (Pop \& Ciascai, 2013). Tlustosova (2006) expresses the view that having a learning difficulty does not mean individuals cannot learn. On the contrary, individuals who have a learning difficulty are often smart, even talented, but unfortunately, they are often labeled dumb and less intelligent, or even lazy. But actually, they only learn differently. Many actually possess average or above average of intellectual abilities. Westwood (2008) refers to "students with learning difficulties" as a label applied to the students who are not able to score the expected school progress. Based on what stated, students with learning difficulties are in need to learn in different ways according to their learning abilities. This concern may help teachers in general and English language teachers in particular to face various challenges in their classes.

English as a Foreign Language EFL teachers face different challenges during teaching students with learning difficulties along with their peers who do not have learning difficulties (Lama, 2019). Therefore, teachers should be trained to enhance skills in how to diagnose students' specific learning needs during instruction and how to provide instructional prescriptions for such needs concurrently (Alhassan \& Abosi, 2014). In this concern, teachers' adequate and ongoing training is highly recommended for their professional development.

Due to the above considerations, there is a need to investigate teachers' concepts about language learning difficulties in English as a foreign language context in Egyptian educational system.

\section{Objectives of the research}

The research aims to achieve the following objectives:

2.1. EFL Teachers' perceptions about language learning difficulties.

2.2. EFL Teachers' perceptions about language learning difficulties' basic concepts.

2.3. EFL Teachers' perceptions about language learning difficulties' intervention techniques.

2.4. EFL Teachers' perceptions about language learning difficulties' class barriers and challenges.

2.5. EFL Teachers' perceptions about language learning difficulties' assessment techniques. 


\section{Significance of the research}

3.1. Discussing a critical issue in foreign language learning which is attempting to identify EFL teachers' perceptions about language learning difficulties.

3.2. Contributing in identifying EFL teachers' basic concepts about language learning difficulties that may affect their future training and professional development.

3.3. Identifying the causes that may contribute to forming teachers' perceptions about language learning difficulties.

3.4. Benefitting those who carrying out teachers' training in assessment and language courses.

3.5. Identifying the relation between teachers' perceptions and other LD aspects such as intervention techniques, barriers and class intervention techniques.

\section{Questions of the research:}

The research seeks to answer the following two main questions:

4.1. What are EFL teachers' perceptions about language learning difficulties?

This major question can be divided into the following sub-questions:

4.1.1. Is there a correlation between EFL teachers' perceptions about language learning difficulties and their basic concepts?

4.1.2. Is there a correlation between EFL teachers' perceptions about language learning difficulties and their intervention techniques?

4.1.3. Is there a correlation between EFL teachers' perceptions about language learning difficulties and class barriers?

4.1.4. Is there a correlation between EFL teachers' perceptions about language learning difficulties and their assessment techniques?

4.2. Are there significant mean differences between participants' perceptions at the four variables of the questionnaire (concepts, techniques, class barriers and assessment techniques)?

\section{Hypotheses of the research}

The research hypothesized the following:

5.1. There is a positive correlation between EFL teachers' perceptions about language learning difficulties according to the variables of concepts, techniques, class barriers and assessment techniques.

5.2. There are no statistically significant differences between participants' mean scores of perceptions at the four variables of the questionnaire (concepts, techniques, class barriers and assessment techniques). 


\section{Research Design}

Due to the descriptive approach of the research, it follows the analytical descriptive design. It aimed at collecting data about teachers' perceptions about language learning difficulties using a research instrument and then analyzing the obtained results.

\section{Instrumentation:}

The research utilized two instruments designed by the researchers: (1) A questionnaire that aimed at identifying EFL teachers' perceptions about language learning difficulties. The questionnaire included four parts: (a) Perception of basic concepts, (b) Perception of intervention techniques, (c) Perception of class barriers and challenges and (d) perception of assessment techniques. (2) An online reflection journal that aimed at identifying participants' views about language learning difficulties in EFL classes in Egypt. The questionnaire was adjusted in terms of validity and reliability, validity was run through content validity (jury validation) and through square root of the (r) value and was (0.80). Using Cronbach Alpha statistic, (r) value was (0.890), which is a high reliability coefficient.

\section{Participants}

A group of (110) English language teachers from Red Sea Governorate, Egypt responded to the questionnaire. Five participants were excluded from the research for not completing either the whole questionnaire or the reflection sheets. They were grouped into one group, and were asked to respond to the instruments online. They were randomly selected according to the time of online submission to the questionnaire and the reflection sheet. The final number of the research participants after the adjustment was (N. 99) English language teachers.

\section{Theoretical Framework:}

The following frame highlights Language Learning Difficulties LLD, EFL teachers' perceptions and concepts about them and the key studies that dealt with learning difficulties. Literature answers the key question of "Is there a difference between the term disability and the term difficulty?" For instance, Lenhard \& Lenhard (2013) refer to Learning difficulties as an umbrella term for academic problems of different causes. The term comprises general learning deficits and low academic performance in specific forms e.g. reading, spelling and arithmetic disorders. Similarly, the term learning disability usually conveys general and long-lasting learning difficulties that are often linked to the field of special education. In this view, MacKay (2009) expresses the view that the term 'learning difficulties' is suited to education 
purposes, since it focuses on the learning process rather than on constructs relating to disorders and disabilities.

Students with learning difficulties are those "who experience problems in learning at school. These problems may be across the curriculum or in specific areas of learning such as literacy or numeracy "(Van Kraayenoord et al., 2011, p. 231). In this view, difficulties with language may affect a learner's speech and later reading, spelling, and written expressions (Osman, 1997). Similarly, Adam \& Tatnall (2010) define learning difficulties as a reference used to a heterogeneous group of students who have significant difficulties in literacy acquisition and numeracy skills. In this context, other terms sometimes used such as 'learning disabilities' and 'special needs'.

Further, Rivalland (2000, p.12) defines learning difficulties as aspects of learning disabilities as the following excerpt states:

"A generic term that refers to a heterogeneous group of students who have significant difficulties in the acquisition of literacy and numeracy and who are not covered in the Commonwealth's definition of a student/child with a disability... Learning disability is believed to be a difficulty that is intrinsic to the individual and not a direct result of other conditions or influences".

The term 'learning difficulty' has been used to describe the significant minority of students who do not seem to respond to their classroom programs, It refers to those students not achieving in classroom programs to the same degree as their peers (Wyatt-Smith, Elkins \& Gunn, 2011).

Dyslexia, Dysgraphia and Dyscalculia are the key language learning difficulties that should be addressed early in language learning classes. Dyslexia is related to difficulties in reading and it may be mild, moderate or severe while Dyscalculia refers to difficulty in mathematics and counting. Dysgraphia is related to difficulties in writing such as poor thinking, poor planning and poor spelling. Multi- sensory, phonetic and technology- based instruction could have positive impact on learning of students with dyslexia, Dysgraphia or dyscalculia. Dyscalculia is described by Ariffin, Halim \& Aziz (2017, P.467) as "one of the learning difficulty that directed to the number and math which can affect math learning". Another view concerning dyslexia is presented by American Psychiatric Association (2000) as cited by Lum, Ullman \& Conti-Ramsden (2013, p.3461) that describes dyslexia as "to have significant difficulties with reading despite appropriate educational opportunities and an absence of intellectual impairments, or an identifiable disease or disorder that might otherwise account for the problem". Dysgraphia was defined by Chung \& Patel (2015, p.27) as "difficulty writing at any level, including letter illegibility, slow rate of writing, difficulty spelling, and 
problems of syntax and composition". Both of the two difficulties affect how EFL teachers plan, teach, manage or assess their classes.

The Canadian Learning Disabilities Association CLDA (2002) cited by Reid (2011) indicates that Learning disabilities are due to genetic and/or neurological factors or injury that alters brain function in a manner that affects one or more processes relate to learning. These disorders are not due primarily to hearing and/or vision problems, social-economic factors, cultural or linguistic differences, lack of motivation, inadequate or insufficient instruction, although these factors may further complicate the challenges faced by individuals with learning disabilities. Learning disabilities may co-exist with other disorders such as attention, behavioral or emotional disorders, sensory impairments, or other medical conditions.

Language learning difficulties can be divided into two types (Kirk \& Chalfant, 1984): developmental learning difficulties and academic learning difficulties. Developmental learning difficulties refer to difficulties relating to the functions of brain and mental and cognitive processes including attention difficulties, perception, memory and thinking, problem solving and oral language comprehension. Academic Learning Difficulties refer to academic difficulties such as difficulty in reading, writing or arithmetic. For students with learning difficulties, writing achievement is often lower than that of their peers (Forgan \& Vaughn, 2000). Generally, students with learning difficulties have some common characteristics such as poor note-taking, inability to complete assignments and perform tasks in time allowed and poor speaking and presentation skills.

Students with learning difficulties often have lower academic selfconcepts than their normally achieving peers, and this is manifested in areas such as reading and writing. An examination of the literature related to the writing of students with learning difficulties shows that these students' problems include: a lack of planning, difficulties in generating ideas and organizing text, problems with mechanics (for example spelling, capitalization and punctuation), difficulties with various aspects of meta-cognitive knowledge (example.g they are less knowledgeable about the process of writing) and in the use of strategies and self-regulation of writing (for example, monitoring and revision) (Wyatt-Smith, Elkins \& Gunn, 2011). Furthermore, educational institutions should focus more on strengths and weaknesses in teaching students with learning difficulties with the aim of enhancing the quality of their education.

In his study, Peculea (2015) expressed the view that learning how to learn can be particularly a struggle for students with learning difficulties. Each student may encounter certain difficulties at one or more school subjects in a certain time, difficulties that seem to be insurmountable and may become constant throughout schooling. Learning difficulties are considered as factors 
of school failure. Accordingly, education stakeholders should address this problem with much concern and this can be done through identifying the acoustic leading to learning difficulties, providing appropriate solutions and ensuring doable strategies for implementing these solutions.

Therefore, learning difficulties are one of the key issues that take the attention of EFL teachers, parents and researchers. They have multiple causes, and so that some learners are not identified in time, or are wrongly labeled with non-assimilation, as slow, lazy or uninvolved. Teachers may feel disappointed, vulnerable, overwhelmed, disillusioned and ineffective, faced with these types of challenges (Jeder, 2014). Accordingly, educators are recommended to make use of recent research in learning difficulties field in order to find suitable learning alternatives that ensure good learning for those poor students. Teachers should be trained to enhance skills in how to diagnose students' specific learning needs during instruction and how to provide instructional prescriptions for such needs concurrently (Alhassan \& Abosi, 2014). Thus, students with learning difficulties should be given the right support through regular development of their learning skills using modern learning tools and technologies.

When diagnosing students with learning difficulties, they may have an average IQ or above, but they may also have a difficulty in one or more academic areas. The prevailing class activities seem to ignore them. They may lack flexibility and diversity that satisfy learners with different needs and different learning styles. Obviously, there are two types of learning difficulties: the first(Developmental Difficulties) are life-long disabilities due to mental or physical or combination of mental and physical impairment. The second (Academic Difficulties) are specific learning difficulties as dyslexia (reading difficulty) dysgraphia (writing difficulty) dyspraxia (motor difficulty) dyscalculia (difficulty performing mathematical calculations) (AlNifayee, 2010). Admittedly, learning difficulties may be caused by factors such as inadequate or inappropriate instruction, socio-economic status or lack of motivation. However, learning disabilities are due to genetic or acquired neurobiological factors.

EFL leaning difficulties, in terms of severity of symptoms, could be mild, moderate and severe. They can be described based on the difficulties in using or acquiring several skills including verbal language (listening\& speaking), reading, written language and mathematics (calculation \& problem solving). Graham et al. (2007) illustrate that students with learning difficulties tend to be inefficient in their approaches to learning due to inappropriate strategies. Students with LD can encounter difficulty in recalling previously learned knowledge and connecting information effectively. They often use lower level, inefficient strategies, such as counting on their fingers to find out number facts or always using "sounding out" to decode previously 
encountered words. These difficulties and their degrees affect how children perform the language.

When children show delay in language development, they are also more likely to display difficulties in peer social interactions and problem solving (Hay et al., 2007). Students with learning difficulties usually have less motivation than others. Therefore, teachers' use of motivational utterances can be a contributing factor to raise students' motivation (Nyborg, 2011). Moreover, positive reinforcement is expected to have a good impact in motivating students with learning difficulties.

Students with specific learning difficulty can respond effectively to teaching approaches. The failure may be due to students being labeled as unmotivated or lazy. Nag \& Snowling (2012, p.2) state that students with learning difficulties can "show less difficulty and others more. The manifestations of a learning difficulty can change over development. What appears to be mild at one age can become a significant problem in another life stage". Learning difficulties can appear in different learning patterns such as specific difficulties with spelling and disorder of written expression.

Ramli \& Tarmizi (2013, p.341) expressed the view that "the way students learn is essentially influenced by the way teachers teach". Similar to common classes' contexts, teachers should be aware that students needs paradigm shift of the teacher to move from rote learning and spoon feed pedagogical to student centered learning. Furthermore, Baglama et al. (2017) suggest that visualization is an effective method for learners to make the data visible, available and clear for learner to structure, organize, evaluate, annotate knowledge and establish communication. Based on the increase in visual data and digital tools, reading and constituting visual data have become a necessity for individuals.

Chen \& Chang (2004) investigated the possible existence of causal links between anxiety and language learning difficulties. Data were provided by 1,187 college students learning English as a foreign language (EFL). The results show that some anxious students have a history of English learning problems, obtain low grades, suffer difficulties with classroom learning, and exhibit poor developmental skills.

These findings imply that students encountering greater difficulties with learning a foreign language also experience higher levels of anxiety.

Similarly, Goncalves \& Crenitte (2014) examined the knowledge and concepts of elementary school teachers about learning difficulties, learning disabilities, and dyslexia. The sample consisted of 31 elementary school teachers. A survey was conducted through a questionnaire. The questionnaire had questions regarding the teacher's knowledge about the definition, causes, and manifestations of learning disorders. Results showed that the teachers demonstrated difficulties for defining disorders, identifying their causes, and 
pointing out their manifestations. Separating the teachers by type of school (public or private) and prior knowledge of the subject, there was no statistically significant difference in most of the answers.

Further, Diaab (2016) conducted a study with the aim of investigating EFL learners' speaking difficulties and the factors underlying this problem with a group of 125 university students participating in the study. Questionnaires and interviews were administered to elicit information about the participants' learning experience, the way they were taught English and speaking difficulties. The obtained data were analyzed using SPSS and content analysis. Results showed that the learners face difficulties in oral communication due to linguistic and psychological barriers. Results also showed that insufficient exposure to the target language and frequent use of Arabic, inside and outside the classroom, were the main factors contributing to their speaking difficulties. Lack of speaking activities and over emphasis on accuracy at the expense of fluency by the teachers were other contributing factors.

West (2016) conducted a qualitative study to examine general education teachers' perception and experiences of adapting instructional accommodations for high school students with learning difficulties in an English general education high school class. A group of (10) participants was selected and the study utilized Face-to-face interviews to collect data. Results of the study verified that due to the lack of pedagogy, content knowledge, training, and their aspirations on how to implement instructional accommodations, general education teachers were not prepared and / or certified to provide instructional accommodations for high school students with specific learning disabilities.

Sainio, Eklund, Ahonen \& Kiuru (2019) also examined the associations between learning difficulties (LD), academic emotions, and academic achievement among 845 Grade 6 adolescents (455 girls, 390 boys). Data on students' achievement in literacy and math, as well as their overall academic achievement, were collected using questionnaires. The results showed, first, that students with reading difficulties had lower hope and higher anxiety toward reading than those without reading difficulties. The study's results indicate that subject-specific academic emotions should be taken into account when considering relations between learning difficulties and academic achievement.

Further, Woodcock, Hitches \& Jones (2019) investigated the relationship between teacher self-efficacy and teachers' causal beliefs towards students with and without specific learning difficulties. Participants included (122) secondary school teachers teaching in eight randomly selected secondary schools. Results showed that teachers reporting higher levels of teacher self-efficacy provided more positive feedback to all students, 
regardless of students' ability levels, effort expenditure, or the presence of specific learning difficulties. Additionally, teachers reporting higher levels of teacher self-efficacy felt less frustration, more sympathy, and held lower expectations of future failure towards students who expended low effort.

To sum up, learning difficulties are different in severity and causes. Academic learning difficulties in language area can be mainly regarded to reading (Dyslexia) and writing (Dysgraphia). Literature attempted to investigate various reasons and attempts between LD and other areas such as instruction, assessment beliefs and others. What are the concepts and perceptions of EFL teachers that may govern their practice with their LD students in their English classes? This is what the present research attempts to answer.

\section{Results}

Results of the questionnaire and the reflective journal were analyzed quantitatively and qualitatively. Quantitative results were obtained from the questionnaire; a group of (99) participants responded to the questionnaire through an online link. The questionnaire included (60) items; they were divided into (4) parts. The first part included 15 items about (perception of basic concepts); part two included (15) items about (perception of intervention techniques); part three included 15 items about (perception of barriers and challenges) and part four included 15 items about perception of assessment techniques). The quantitative input was obtained through the analysis of items in the questionnaire. Both validity and reliability measurements were obtained before running the analysis. Validity was run through content validity (jury validation) and through square root of the (r) value and was (0.80). Using Cronbach Alpha statistic, reliability value was calculated as (0.890), which is a high reliability coefficient as the following table (1) shows:

Table (1) Reliability value of the questionnaire

\begin{tabular}{|l|l|}
\hline Cronbach Alpha & Number of Items \\
\hline 0.890 & 60 \\
\hline
\end{tabular}

Before running the statistical analysis over the questionnaire, a test of normality for the items of the questionnaire was run using Shapiro-Wilk statistic to verify if items were normally distributed as table (2) shows: 
Table (2) Test of Normality

\begin{tabular}{|l|l|l|l|}
\hline \multirow{2}{*}{} & \multicolumn{4}{|l|}{ Kolmogorov-Smirnov ${ }^{\mathrm{a}}$} \\
\cline { 2 - 4 } & Statistic & df & Sig. \\
\hline PartA & .180 & 45 & .001 \\
PartB & .193 & 45 & .000 \\
PartC & .237 & 45 & .000 \\
PartD & .217 & 45 & .000 \\
\hline
\end{tabular}

a. Lilliefors Significance Correction

The table shows that the significance level of (.000) at the four variables of the questionnaire. This shows that items of the questionnaire are normally distributed and the questionnaire is valid for running the next correlation analysis procedure. The total number of the items in the questionnaire (60) were grouped in (4) parts, each of which included (15) items to measure participants' perceptions about English language learning difficulties in English as a Foreign Language EFL classes. A correlation analysis was run to identify the correlation between the four parts of the questionnaire as the following table (3) shows.

Table (3) Spearman correlation of overall scores

\begin{tabular}{|ccc|c|c|}
\hline & & items & scores \\
\hline Spearman's rho & items & Correlation Coefficient & 1.000 & $-.006-$ \\
& & Sig. (2-tailed) &. & .933 \\
& & $\mathrm{~N}$ & 180 & 180 \\
\cline { 2 - 5 } & scores & Correlation Coefficient & $-.006-$ & 1.000 \\
& & Sig. (2-tailed) & .933 &. \\
& $\mathrm{~N}$ & 180 & 180 \\
\hline
\end{tabular}

The above table shows that there is a strong correlation between the different items in the questionnaire over the Likert scale (Agree (3), Neutral (2) and disagree (1). Since the correlation is (.933) and is close to (1), the correlation between items is highly positive. To verify the correlation between the four sections of the questionnaire using the ordinal scale of the questionnaire, the following correlation analysis using Spearman's statistic was run as table (4) indicates. 
Table (4) Spearman correlation of the four sections

\begin{tabular}{|ccc|}
\hline Spearman's rho & PartA & Correlation Coefficient \\
& Sig. (2-tailed) \\
& $\mathrm{N}$ \\
\cline { 2 - 3 } & PartB & Correlation Coefficient \\
& Sig. (2-tailed) \\
& $\mathrm{N}$ \\
\cline { 2 - 3 } & PartC & Correlation Coefficient \\
& Sig. (2-tailed) \\
& $\mathrm{N}$ \\
\cline { 2 - 3 } & PartD & Correlation Coefficient \\
& Sig. (2-tailed) \\
& $\mathrm{N}$ \\
& & \\
& &
\end{tabular}

The above table shows the correlations of the four parts of the questionnaire that range between $(0-1)$, which is a very high correlation at the level (sig .001).The correlation values for the four items were $(0.820,0.854,0.748$ $\& 1)$, respectively. The table also shows that there is a strong correlation between (part A) Perception of basic concepts, (part B) Perception of intervention techniques, (part C) perception of barriers and challenges and (part D) perception of assessment techniques. Since the obtained correlation values are close to (1), this means that the correlation is positive and high as well. This result also means that perceptions of the participants are high in the four parts of the questionnaire. The following table (5) describes the differences in means.

Table (5) Paired Samples Statistics

\begin{tabular}{|cc|c|c|c|c|}
\hline & & Mean & $\mathrm{N}$ & Std. Deviation & Std. Error Mean \\
\hline \multirow{2}{*}{ Pair 1 } & items & 2.50 & 180 & 1.121 & .084 \\
& scores & 78.46 & 180 & 66.038 & 4.922 \\
\hline
\end{tabular}

Table (5) shows a description for the (60) items of the questionnaire in its four parts and the responses of the participants (90) over the Likert scale (coded into 1-2-3), therefore multiplying the max score of the scale (3) in the number of items (60) shows the total items score (180). This correlation is identified in the following table (6). 
Table (6) Paired Samples Correlations

\begin{tabular}{|lc|c|c|c|}
\hline & $\mathrm{N}$ & Correlation & Sig. \\
\hline Pair 1 & $\begin{array}{c}\text { items \& } \\
\text { scores }\end{array}$ & 180 & $-.009-$ & .902 \\
\hline
\end{tabular}

The above table shows the degree of significance between the items and the scores. The obtained value (.902) is highly significant and indicates different correlation between the items. To verify this difference between the four sections of the questionnaire, an analysis of means differences was run as the following table shows. Table (7) shows that there are mean differences between participants' responses to the four sections of the questionnaire.

Table (7) One-Sample Statistics

\begin{tabular}{|c|c|c|c|c|}
\hline & N & Mean & Std. Deviation & Std. Error Mean \\
\hline PartA & 45 & 80.16 & 69.792 & 10.404 \\
PartB & 45 & 77.11 & 58.869 & 8.776 \\
PartC & 45 & 78.78 & 72.147 & 10.755 \\
PartD & 45 & 77.78 & 64.765 & 9.655 \\
\hline
\end{tabular}

The table shows participants' means in responding to the four sections of the questionnaire; Part (A) The perception was the highest (80.16), followed by part (C) which was (78.78), then part (D) (77.78) and part (B) was (77.11). This result shows that participants were first aware of the basic concepts of LD in their English classes, then the barriers and challenges, then assessment techniques and at the least part was (the intervention techniques), respectively.

\section{Qualitative results:}

Qualitative results were obtained from the online reflection journal of the participants via Blogger. The journal included demographic data and open ended reflection questions. A number of (21) males and (68) females responded to the journal. The journal helped the participants to reflect on their practices with reference to LD. Analyzing their comments showed that they were aware with the different areas covered on the questionnaire. An example was given by Maha stating that "I think to know more about learning difficulties is very important, however dealing with these types of students needs more specialized teachers. I think the main role of teachers is to know how to recognize and discover theses students and I prefer the shadow teacher who is responsible for them".

Similarly, Rasha highlighted the value of teacher training in the field of LD, but did not support shadow teachers, stating that "For me, the students with learning difficulties have no better chance of learning so it is better to 
train the teacher to deal with them and help students to give an equal chance for learning. It will lead to minimize learning gap among them... and help raising the professional development of teachers... I think it is better than shadow teachers but it takes more time and effort".

Practicing intervention more than knowledge - as a concept- was mentioned by many participants in their journals, Lamiaa for instance, stated that" about class barriers, it is necessary too, we need to know what could affect or even cause such behavior for students. we should be helpful and supportive.. Without the right intervention techniques, we can do more harm than good for students". The above comments and reflections assure that intensive teacher training for EFL teachers should be carried out in the field of LD; this will help them from mere knowledge to effective intervention.

The reflective journals also highlighted the affective variable in handling LD in EFL classes. Shahine, for instance stated that "teaching is not only the knowledge or skills obtained from a course, rather, the attitude and affection gained as well. The relation between the content, the teacher and the students is mutual, therefore, teachers need to "know how" to deal with LD in their classes". This was also explained - with an example- by Randa, stating that " teachers should be aware of these concepts of LD specially that we have students in our schools with learning difficulties... how to treat with them, to make them feel comfortable and not feeling they are less than their peers...also before I know that, I have one boy [with LD] and I was always complaining from not knowing what was going with him". To conclude, teachers' reflective journals highlighted the importance of the four areas of the questionnaire through their career experiences. They also recommended professional development strategies to be followed by their peer teachers to integrate LD trainings in TEFL training and curricula.

\section{Discussion}

The research investigated English language teachers' perceptions about learning difficulties in their English classes. The following is a discussion for the two hypotheses of the research.

\subsection{Testing the first hypothesis}

Hypothesis (1) predicted that there would be a positive correlation between EFL teachers' perceptions about language learning difficulties according to the variables of concepts, techniques, class barriers and assessment techniques. Analysis of the obtained data showed that all participants have high perceptions of the basic concepts of LD in their English classes (M. 80.16), a high level of intervention techniques perception (M. 77.11), a high level of perceptions of class barriers and challenges perception (M. 78.78) and high perceptions of assessment techniques of 
language learning difficulties (M. 77.78). The inter-correlation between the parts are: (a) correlation values between the first part and the other parts were $(.875, .755, \& .820)$, respectively. (b) Correlation values between the second part and the other parts were $(.875, .812, \& \quad .854)$, respectively. (c) Correlation values between the third part and the other parts were (.755, $.812, \&$.748), respectively. (d) Correlation values between the last part and the other parts were $(.820, .854, \& .748)$, respectively. This result assures that there is a strong positive correlation between participants' perceptions about LD and their concept, intervention techniques, class barriers and assessment techniques.

\subsection{Testing the second hypothesis}

The research hypothesized that there would be no significant mean differences between participants' perceptions at the four variables of the questionnaire (concepts, techniques, class barriers and assessment techniques). Running paired-sample analysis showed that there are means differences between the four parts of the test (sig .902). To verify this difference, another statistic was run that showed that the difference in mean was attributed to the first part (the concepts M. 80.16), followed by part C (barriers M. 78.78), then part D (assessment M. 77.78) and the least was part B (the techniques $M$. 77.11). This result agrees with the alternative hypothesis and rejects the null hypothesis, therefore, proves that there are statistically significant means differences between the participants in the different parts of the questionnaire.

The area of Language Learning Difficulties (LLD) has been a topic for various studies e.g. Chen \& Chang (2004), Gonçalves \& Crenitte (2014), Korhonen, Linnanmäki \& Aunio (2014), Alawadh (2016), Diaab (2016), West (2016), Okanlawn (2017), Sainio et al. (2019), Woodcock, Hitches \& Jones (2019), and Woodcock (2020) . A key obtained result from the questionnaire is that the participants were first aware of the basic concepts of learning difficulties in their English classes, then the barriers and challenges, then assessment techniques and at the least part was the intervention techniques, respectively.

Results of this study is consistent with a study by Woodcock (2020), which found that there were no differences between teachers' beliefs about inclusive education and the attribution responses toward students with and without learning difficulties. Additionally, the study stated that teachers' beliefs in inclusive education can be influential toward the success of inclusive practices and also students' successes and failures within the classroom. Having a clear understanding and high expectations toward students with learning difficulties is important if these students are to reach their potential. 
On the contrary, the results of this study disagree with other studies. For instance, Gonçalves \& Crenitte (2014) conducted a study to investigate the knowledge and concepts of elementary school teachers about learning difficulties, learning disabilities, and dyslexia. Sample consisted of 31 elementary school teachers. A survey was conducted through a questionnaire. The questionnaire includes questions about the teacher's knowledge, the definition, causes, and manifestations of learning disorders. Results showed that the teachers demonstrated difficulties for defining disorders, identifying their causes, and pointing out their manifestations. Separating the teachers by type of school (public or private) and prior knowledge of the subject, there was no statistically significant difference in most of the answers.

Although the study confirms that teachers have high perceptions of learning difficulties in their English classes, this is not consistent with the study results of Alawadh (2016) which showed that teachers had limited awareness of language learning difficulties and required specific training and further education to be able to address learning difficulties. In this view, Bowen \& Rude (2006) conducted a study that concluded that assessment practices can benefit learners with learning difficulties by moving beyond eligibility determination to more meaningful early intervening and Response to Intervention models. This is consistent with the current study which asserts that teachers should have high perceptions on assessment techniques as a crucial factor and is closely correlated with their class intervention techniques.

To sum, the obtained results confirm that the research participants have high perception level for learning difficulties in four main areas (basic concepts, intervention techniques, class barriers and assessment techniques), respectively.

\section{Recommendations of the research}

In the light of the obtained data, the research recommends that EFL educators should adopt clear conceptual awareness concerning students with learning difficulties. Similarly, inclusive education should take a great deal of concern across educational institutions. Another recommendation is that EFL Teachers should be trained on early interventions' techniques that could benefit their students. They also should adopt Multi- sensory approach to be integrated in teaching students with learning difficulties. A key recommendation is that mobile technology should be incorporated in teaching students with learning difficulties and to be integrated in the different EFL enrichment programs of students with special needs that can cope with their learning settings. 


\section{Conclusion and implications}

Using the descriptive analytical research designs, the research utilized a questionnaire that aimed at identifying EFL teacher's concepts about language learning difficulties and a reflection journal as well. Results showed that there is a strong positive correlation between participants' perceptions about English language learning difficulties and LD concepts, intervention techniques, barriers and assessment techniques. Results also rejected the null hypothesis and accepted the alternative one which confirms the difference in participants' means in the four areas of the questionnaire. The reflection journal also confirmed that the teachers were aware of the concepts, barriers, techniques and assessment procedures of EFL learning difficulties.

Implications of the research can be beneficial for EFL teachers, course designers and teacher training institutions. As to EFL teachers, they can use the variables in the questionnaire to review and refine their concepts about LD and how to carry out their lessons considering the four areas mentioned in the questionnaire. They can review their concepts, intervention skills and assessment procedures to overcome the challenges they may face in classes with LD challenges. Course designers can make use of the recommendations of the research to include LD challenges in the teacher guides, activities' procedures and lessons objectives. Teacher training institutions can make use of the results when designing their TEFL training programs and materials that should consider the four areas discussed in the research.

\section{References:}

1. Adam, T. \& Tatnall, A. (2010). Use of ICT to Assist Students with Learning Difficulties: An Actor-Network Analysis. In Key Competencies in the Knowledge Society (pp. 1-11). Berlin, Heidelberg: Springer. doi: 10.1007/978-3-642-15378-5_1

2. Alawadh, A. (2016) Teachers Perceptions of the Challenges Related to Provision of Services for Learners with Specific Learning Difficulties (Dyslexia) in Kuwaiti Government Primary Schools. (Doctoral Dissertation). University of York, UK.

3. Alhassan, A. R. \& Abosi, O. C. (2014). Teacher effectiveness in adapting instruction to the needs of pupils with learning difficulties in regular primary schools in Ghana. Sage Open, 4(1), 2158244013518929.

4. Al-Nifayee, A. M. (2010). The Effectiveness of the Instrumental Enrichment Approach on the Enhancement of Reading Comprehension Skills of Preparatory Stage Pupils with English Language Learning Difficulties.(M.A Thesis).Faculty of Education, Taif University, KSA. 
5. Ariffin, M. M., Halim, F. A. A. \& Aziz, N. A. (2017). Mobile application for dyscalculia children in Malaysia. In Proceedings of the 6th International Conference on Computing Informatics (pp.467472).

6. Baglama, B., Yucesoy, Y., Uzunboylu, H.\& Özcan, D. (2017). Can Infographics Facilitate theLearning of Individuals with Mathematical Learning Difficulties? International Journal of Cognitive Research in Science, Engineering and Education/IJCRSEE, 5(2), 119-127. Doi:10.5937/IJCRSEE1702119B

7. Bowen, S. K., \& Rude, H. A. (2006). Assessment and Students with Disabilities: Issues and Challenges with Educational Reform. Rural Special Education Quarterly, 25(3), 24-30.

Doi:10.1177/875687050602500304

8. Chen, T. Y., \& Chang, G. B. (2004). The relationship between foreign language anxiety and learning difficulties. Foreign language annals, 37(2), 279-289.

9. Chung, P. \& Patel, D. R. (2015). Dysgraphia. International Journal of Child and Adolescent Health, 8(1), 27.

10. Diaab, S. (2016).Role of Faulty Instructional Methods in Libyan EFL Learners' Speaking Difficulties.Procedia - Social and Behavioral Sciences, 232(1), 338-345. Doi: 10.1016/j.sbspro.2016.10.032

11. Forgan, J. W., \& Vaughn, S. (2000). Adolescents with and without LD make the transition to middle school. Journal of Learning Disabilities, 33(1), 33-43.

12. Gonçalves, T. D. S., \& Pinheiro Crenitte, P. A. (2014). Conceptions of Elementary School Teachers about Learning Disorders. Revista CEFAC, 16(3).

13. Graham, L., Bellert, A., Thomas, J.\& Pegg, J. (2007). QuickSmart: A Basic Academic Skills Intervention for Middle School Students with Learning Difficulties. Journal of Learning Disabilities, 40(5), 410419.

14. Hay, I., Elias, G., Fielding-Barnsley, R., Homel, R.\& Freiberg, K. (2007). Language Delays, Reading Delays, and Learning Difficulties: Interactive Elements Requiring Multidimensional Programming. Journal of Learning Disabilities, 40(5), 400-409.

15. Jeder, D. (2014). Practical Aspects of the Continuous Training Activities Regarding the Learning Difficulties.Procedia-Social and Behavioral Sciences, 116(1), 2125-2130. Doi: 10.1016/j.sbspro.2014.01.531

16. Kirk, S. A. \& Chalfant, J. C. (1984).Academic and Developmental Learning Disabilities ( $1^{\text {st. }}$ ed.): Love Pub. Co. 
17. Korhonen, J., Linnanmäki, K. \& Aunio, P. (2014). Learning Difficulties, Academic Well-Being and Educational Dropout: A Person- Centred Approach. Learning and Individual Differences, 31(1), 1-10. doi: 10.1016/j.lindif.2013.12.011

18. Lama, A. (2019). Difficulties in English Language Learning for Students with Dyslexia. SEEU Review, 14(1), 196-206.DOI: 10.2478/seeur-2019-0011

19. Lenhard, W., \& Lenhard, A. (2013). Learning Difficulties. Learning Disabilities, 25, 33-45.

20. Lum, J. A., Ullman, M. T. \& Conti-Ramsden, G. (2013). Procedural learning is impaired in dyslexia: Evidence from a meta-analysis of serial reaction time studies. Research indevelopmental disabilities, 34(10), 3460-3476.

21. MacKay, T. (2009). Severe and complex learning difficulties: issues of definition, classification and prevalence. Educational and Child Psychology, 26(4), 9-18.

22. Nag, S.\& Snowling,. (2012). School Underachievement and Specific Learning Difficulties.IACAPAP E- Textbook of Child and Adolescent Mental Health.(PP. 1-44). Geneva: International Association for Child and Adolescent Psychiatry and Allied Professions.

23. Nyborg, G. (2011). Teachers' Use of Motivational Utterances in Special Education in Norwegian Compulsory Schooling. A Contribution Aimed at Fostering an Inclusive Education for Pupils with Learning Difficulties? International Journal of Special Education, 26(3), 248-259.

24. Okanlawon, A. E. (2017). Teaching Chemistry to Students with Learning Difficulties: Exemplary Adaptive Instructional Practices of Experienced Teachers. IFE Psychologies: An International Journal, 25(2), 262-279.

25. Osman, Betty. B. (1997). Learning disabilities and ADHD: A family guide to living and learning together. USA: J. Wiley \& Sons Inc. ISBN: 0-471-15510-1

26. Peculea, L. (2015). Investigating learning difficulties at Romanian language and literature subject in perspective of learning to learn competence development. Procedia-Social and Behavioral Sciences, 180, 666-673. doi: 10.1016/j.sbspro.2015.02.176

27. Pop, Cristina, F. \& Ciascai, Liliana. (2013). What do Romanian teachers know about learning difficulties. Acta Didactica Napocensia, 6(3), 11- 18.

28. Ramli, F., Shafie, N.\& Tarmizi, R. A. (2013). Exploring Student's indepth Learning Difficulties in Mathematics through Teachers' 
Perspective. Procedia-Social and Behavioral Sciences, 97, 339-345. doi: 10.1016/j.sbspro.2013.10.243

29. Reid, G. (2011)Dyslexia: A Complete Guide for Parents and Those Who Help Them: USA: Wiley \& Sons Inc.

30. Rivalland, J. (2000). Definitions \& identification: Who are the children with learning difficulties? Australian Journal of Learning Difficulties, 5(1), 12-16. doi: 10.1080/19404150009546621

31. Sainio, P. J., Eklund, K. M., Ahonen, T. P., \& Kiuru, N. H. (2019). The role of learning difficulties in adolescents' academic emotions and academic achievement. Journal of learning disabilities, 52(4), 287298. DOI: $10.1177 / 0022219419841567$

32. Tlustosova, Pavla. (2006). Teaching English to children with specific learning difficulties. (Doctoral dissertation). Pedagogical Faculty, Masaryk University, Brno, Czech Republic.

33. Van Kraayenoord, C. E., Moni, Karen. B., Jobling, Anne, Elkins, John, Koppenhaver, David, \& Miller, Robyn. (2011). The Writing Achievement, Metacognitive Knowledge of Writing and Motivation of Middle-School Students with Learning Difficulties. In C. WyattSmith, J. Elkins, \& S. Gunn (Eds.), Multiple Perspectives on Difficulties in Learning Literacy and Numeracy (pp. 213-234). Dordrecht: Springer Netherlands.

34. West, D. F. (2016). General education teachers' perceptions and experiences of adapting instructional strategies for students with learning disabilities in the regular English classroom (Doctoral dissertation). Capella University, USA.

35. West , P.(2008). What Teachers Need to Know about Learning

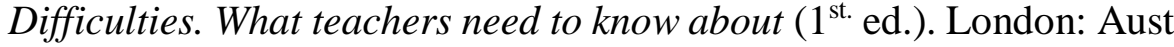
Council for Ed Research. ISBN: 0864319363, 9780864319364

36. Woodcock, S., Hitches, E., \& Jones, G. (2019). It's not you, it's me: Teachers' self-efficacy and attribution beliefs towards students with specific learning difficulties. International Journal of Educational Research, 97, 107-118.Doi: 10.1016/j.ijer.2019.07.007

37. Woodcock, S. (2020). Teachers' beliefs in inclusive education and the attribution responses toward students with and without specific learning difficulties. Dyslexia (1), 1-16. DOI: 10.1002/dys.1651

38. Wyatt-Smith, C., Elkins, J. \& Gunn, S. (2011). Multiple Perspectives on Difficulties in Learning Literacy \& Numeracy. Heidelberg, Germany: Springer. 


\section{Appendix}

(Senior teachers' Perceptions about Language Learning Difficulties in English as a Foreign Language EFL classes)

\section{Dear Participants,}

This questionnaire aims at identifying your perception-as a teacherabout learning difficulties in English language classes. It is an instrument from a research that identifies teachers' perceptions about English language learning difficulties in English as a Foreign Language EFL classes. Kindly use the following table to state your bio-data, then use the scale provided to state your choices.

\begin{tabular}{|l|ll|}
\hline \multicolumn{2}{|l|}{ Bio-Data } \\
\hline Name (Optional) & & \\
\hline Affiliation & Teacher $\square$ & Senior teacher $\square \quad$ Supervisor $\square$ \\
\hline Phone & & \\
\hline Email & & \\
\hline
\end{tabular}

\begin{tabular}{|c|c|c|c|c|}
\hline No & Items & 3 & 2 & 1 \\
\hline 1. & 1.Perception of Basic Concepts & Aware & Neutral & Unaware \\
\hline 1.1 & $\begin{array}{l}\text { I am aware with the different academic learning } \\
\text { difficulties and disabilities. }\end{array}$ & & & \\
\hline 1.2 & $\begin{array}{l}\text { I believe identifying prefixes, suffixes and roots are } \\
\text { reading difficulties. }\end{array}$ & & & \\
\hline 1.3 & $\begin{array}{l}\text { I am aware that sound discrimination difficulty is a } \\
\text { reading difficulty. }\end{array}$ & & & \\
\hline 1.4 & $\begin{array}{l}\text { I can define and explain Dyslexia with reference to my } \\
\text { English classes. }\end{array}$ & & & \\
\hline 1.5 & $\begin{array}{l}\text { I am aware of learning difficulties early intervention } \\
\text { techniques. }\end{array}$ & & & \\
\hline 1.6 & $\begin{array}{l}\text { I am aware of follow up techniques in my English } \\
\text { classes. }\end{array}$ & & & \\
\hline 1.7 & I know what a multi-sensory learning approach is. & & & \\
\hline 1.8 & I am aware of age factor in screening the students. & & & \\
\hline 1.9 & I am aware of dyslexia types. & & & \\
\hline 1.10 & I am aware of developmental learning difficulties. & & & \\
\hline 1.11 & I am aware of language mechanics problems. & & & \\
\hline 1.12 & $\begin{array}{l}\text { I am aware of the concepts of disorders, difficulties and } \\
\text { disabilities. }\end{array}$ & & & \\
\hline 1.13 & I recognize the features of different learning difficulties. & & & \\
\hline 1.14 & $\begin{array}{l}\text { I am aware of the different characteristics of learners } \\
\text { with learning difficulties in my English classes. }\end{array}$ & & & \\
\hline 1.15 & $\begin{array}{l}\text { I am aware of the relation between child development } \\
\text { and learning difficulties. }\end{array}$ & & & \\
\hline 2 & 2.Perception of Intervention Techniques & Aware & Neutral & Unaware \\
\hline 2.16 & $\begin{array}{l}\text { I am familiar with Dyslexia treatment techniques in my } \\
\text { English classes. }\end{array}$ & & & \\
\hline
\end{tabular}




\begin{tabular}{|c|c|c|c|c|}
\hline 2.17 & $\begin{array}{l}\text { I am familiar with Dysgrahia treatment techniques in my } \\
\text { English classes. }\end{array}$ & & & \\
\hline 2.18 & $\begin{array}{l}\text { Following instruction problems is a characteristic of } \\
\text { dyslexic children. }\end{array}$ & & & \\
\hline 2.19 & $\begin{array}{l}\text { I can run early intervention techniques in my English } \\
\text { classes. }\end{array}$ & & & \\
\hline 2.20 & $\begin{array}{l}\text { I can handle follow-up techniques in my English } \\
\text { classes. }\end{array}$ & & & \\
\hline 2.21 & $\begin{array}{l}\text { I am aware of how, when and why to use a separate } \\
\text { room for intervention. }\end{array}$ & & & \\
\hline 2.22 & $\begin{array}{l}\text { I am aware of handling co-teachers and teams for } \\
\text { intervention. }\end{array}$ & & & \\
\hline 2.23 & $\begin{array}{l}\text { I am aware that curricula are part of the intervention } \\
\text { techniques }\end{array}$ & & & \\
\hline 2.24 & I can diagnose the different learning difficulties. & & & \\
\hline 2.25 & $\begin{array}{l}\text { I am aware of academic learning difficulties screening } \\
\text { techniques. }\end{array}$ & & & \\
\hline 2.26 & $\begin{array}{l}\text { I am aware of developmental learning difficulties } \\
\text { screening techniques. }\end{array}$ & & & \\
\hline 2.27 & I am aware of IQs and learning difficulties relationship. & & & \\
\hline 2.28 & $\begin{array}{l}\text { I am acquainted with symptoms severity and their } \\
\text { handling techniques. }\end{array}$ & & & \\
\hline 2.29 & I am aware of intervention tools and instruments. & & & \\
\hline 2.30 & $\begin{array}{l}\text { I am aware of writing reports and recommendations for } \\
\text { parents and administration about students' academic } \\
\text { progress. }\end{array}$ & & & \\
\hline 3 & 3.Perception of Barriers and Challenges & Aware & Neutral & Unaware \\
\hline 3.31 & I have been trained on handling dyslexic students. & & & \\
\hline 3.32 & $\begin{array}{l}\text { I have been trained on learning difficulties in English } \\
\text { language classes. }\end{array}$ & & & \\
\hline 3.33 & $\begin{array}{l}\text { I can work with a team for intervention in my English } \\
\text { classes. }\end{array}$ & & & \\
\hline 3.34 & $\begin{array}{l}\text { I can make use of my English class curriculum in } \\
\text { intervention programs }\end{array}$ & & & \\
\hline 3.35 & $\begin{array}{l}\text { School administration assists your training and } \\
\text { professional development plan. }\end{array}$ & & & \\
\hline 3.36 & There is a trained team in my school for intervention. & & & \\
\hline 3.37 & $\begin{array}{l}\text { The lesson plan includes parts for students with learning } \\
\text { difficulties. }\end{array}$ & & & \\
\hline 3.38 & $\begin{array}{l}\text { The supervisor assists me in handling students' learning } \\
\text { difficulties. }\end{array}$ & & & \\
\hline 3.39 & $\begin{array}{l}\text { The school should handle trainings for professional } \\
\text { development. }\end{array}$ & & & \\
\hline 3.40 & $\begin{array}{l}\text { I am aware of my school policy regarding students with } \\
\text { learning difficulties. }\end{array}$ & & & \\
\hline 3.41 & $\begin{array}{l}\text { I am aware of the learning difficulties department and } \\
\text { its different programs. }\end{array}$ & & & \\
\hline
\end{tabular}




\begin{tabular}{|c|c|c|c|c|}
\hline 3.42 & $\begin{array}{l}\text { I am aware of the required procedures in both academic } \\
\text { and developmental learning difficulties in my English } \\
\text { classes. }\end{array}$ & & & \\
\hline 3.43 & $\begin{array}{l}\text { I am aware of adaptive teaching and student-centered } \\
\text { learning. }\end{array}$ & & & \\
\hline 3.44 & I am aware of the various causes of learning difficulties. & & & \\
\hline 3.45 & $\begin{array}{l}\text { I am aware of family, friends and administration effect } \\
\text { in handling learning difficulties in my English classes. }\end{array}$ & & & \\
\hline 4 & 4.Perception of Assessment Techniques & Aware & Neutral & Unaware \\
\hline 4.46 & $\begin{array}{l}\text { I am aware of the concepts of assessment, evaluation } \\
\text { and measurement. }\end{array}$ & & & \\
\hline 4.47 & I am aware of student-centered assessment. & & & \\
\hline 4.48 & $\begin{array}{l}\text { I am aware of learning difficulties assessment } \\
\text { techniques. }\end{array}$ & & & \\
\hline 4.49 & $\begin{array}{l}\text { I am aware of the relation between the types of } \\
\text { assessments and the type of learning difficulties. }\end{array}$ & & & \\
\hline 4.50 & $\begin{array}{l}\text { I can use both formative and summative assessments in } \\
\text { dyslexia context. }\end{array}$ & & & \\
\hline 4.51 & $\begin{array}{l}\text { I can use both formative and summative assessments in } \\
\text { Dysgrahia context. }\end{array}$ & & & \\
\hline 4.52 & $\begin{array}{l}\text { I am aware of designing an assessment plan for students } \\
\text { with learning difficulties. }\end{array}$ & & & \\
\hline 4.53 & $\begin{array}{l}\text { I recognize the relation between learning difficulties and } \\
\text { assessment techniques. }\end{array}$ & & & \\
\hline 4.54 & $\begin{array}{l}\text { I can design assessment tools relevant to students with } \\
\text { learning difficulties. }\end{array}$ & & & \\
\hline 4.55 & $\begin{array}{l}\text { I am aware of the difference between students with and } \\
\text { without learning difficulties. }\end{array}$ & & & \\
\hline 4.56 & $\begin{array}{l}\text { I can design and use assessment tools based on the } \\
\text { curriculum taught for students with learning difficulties. }\end{array}$ & & & \\
\hline 4.57 & $\begin{array}{l}\text { I am aware of how to assess a specific learning } \\
\text { difficulty such as spelling. }\end{array}$ & & & \\
\hline 4.58 & $\begin{array}{l}\text { I am aware of the various correction techniques } \\
\text { followed in learning difficulties cases. }\end{array}$ & & & \\
\hline 4.59 & $\begin{array}{l}\text { I am aware of assessment challenges in English classes } \\
\text { with dyslexic and dysgraphic students. }\end{array}$ & & & \\
\hline 4.60 & $\begin{array}{l}\text { I am aware of integrating technology in assessing } \\
\text { students with learning difficulties in my English classes. }\end{array}$ & & & \\
\hline
\end{tabular}

